\title{
Littoral cell angioma: A case report
}

\author{
Littoral hücreli anjiom: Olgu sunumu
}

Güliz ÖZKÖK, Funda TAŞLI, Sibel DEMIR KEÇECİ, Hakan POSTACI

\begin{abstract}
We report the case of a 43-year-old male with a littoral cell angioma. Clinical examination of the spleen revealed multiple cystic masses surrounded by normal splenic tissue. Histopathologic and immunohistochemical findings confirmed the diagnosis of a littoral cell angioma. The rarity in the literature of littoral cell angiomas is striking.
\end{abstract}

Key words: Littoral cell angioma, Spleen, Vascular tumor

\section{ÖZET}

$\mathrm{Bu}$ yazıda splenektomi materyelinde littoral hücreli anjiom tanıs1 olan 43 yaşında bir erkek hasta sunulmuştur. Hastanın klinik incelemesinde dalakta çok sayıda kistik kitleden oluşan lezyon saptanmıştır. Histopatolojik ve immunohistokimyasal bulgular littoral hücreli anjiom tanısını desteklemiştir. Lezyon son derece nadir olması nedeni ile tartışmaya değer bulunmuştur.

Anahtar kelimeler: Littoral hücreli anjiom, Dalak, Vasküler tümör

Güliz Özkök, Funda Taşlı (凹), Hakan Postacı

Pathology Clinic, Izmir Training and Research Hospital, Izmir, Turkey

e-mail:fundadr@gmail.com

Sibel Demir Keçeci

Pathology Clinic, Izmir Buca Gynecology and Obstetrics Hospital, Izmir, Turkey

Submitted/Gönderilme: 20.10 .2013

Accepted/Kabul: 25.11.2013

\section{Introduction}

Vascular tumors are the most common primary tumors of the spleen. Most of these lesions are derived from vascular endothelium and can be classified as benign hemangiomas [1]. Although splenic hemangiomas appear similar to hemangiomas of other anatomical sites, littoral cell angioma (LCA) is unique to this organ. LCA derives from the littoral cells lining the splenic red pulp sinuses [2-5]. Its morphologic and immunologic features are different from the features of the cavernous and capillary hemangiomas [2]. Most of littoral cell angiomas are discovered incidentally in materials from splenectomies removed for other reasons $[1,2]$.

We describe a case of LCA which was discovered incidentally in splenectomy material removed for diagnostical purposes.

\section{Case Report}

A 43-year-old male presented with fatigue, weight loss and weakness. Physical examination revealed only raised blood urea nitrogen of $67 \mathrm{mg} / \mathrm{dl}$. An abdominal ultrasound examination revealed mild splenomegaly with multiple hypo-echogenic lesions. This was confirmed by magnetic resonance imaging which showed multiple cystic masses with hyperintensity surrounded by normal splenic tissue. These lesions were interpreted as leukemic infiltrations or lymphoma spread. Lymphoma was ruled out by computed tomography of the neck and the thorax. Subsequently, the patient underwent splenectomy.

The resected specimen was $22 \mathrm{~cm}$ and weighed 545 grams. The capsule was intact with minimal nodularity. On sections, splenic tissue was almost completely replaced by nodular spongy dark lesions, ranging in diameter from 0.1 to $4 \mathrm{~cm}$. Histological examination revealed diffuse replacement of splenic red pulp by nodular lesions characterized by anastomosing vascular channels (Figure 1). At the periphery of the lesion, anostomosing vascular channels were continuous with splenic sinuses and had a few papillary 


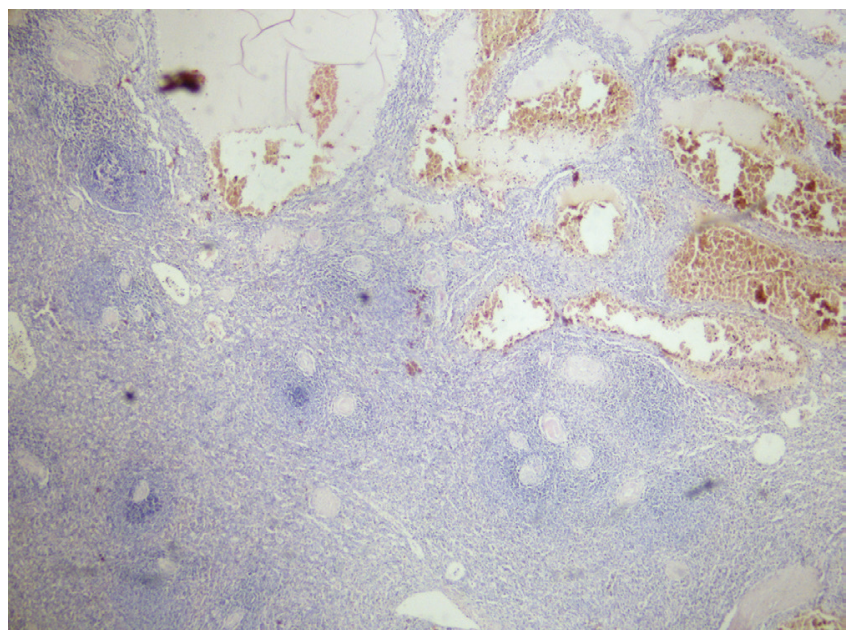

Figure 1. Vascular spaces of varying width are located in the red pulp (HE, X40).

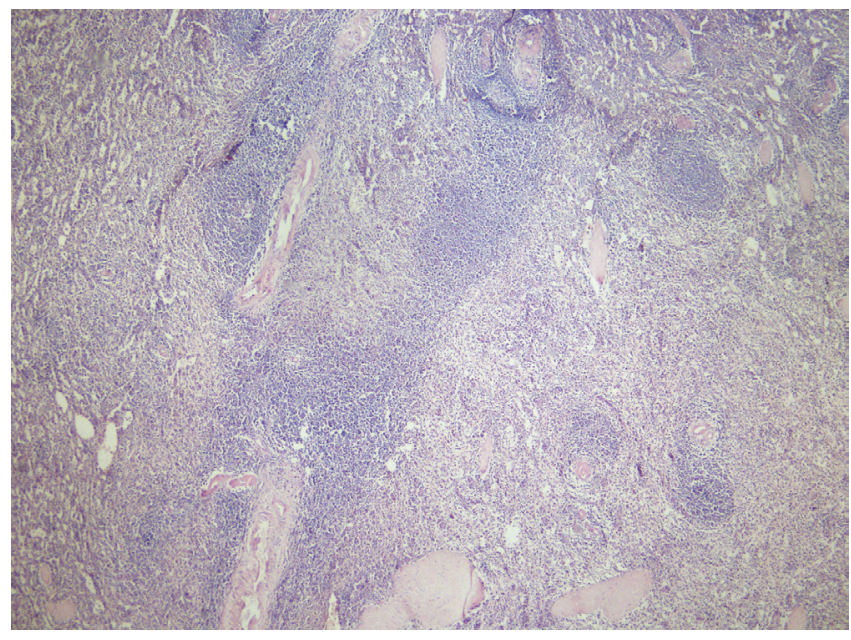

Figure 2. Histology of LCA reveals communications with normal splenic parenchyma (HE, X40).

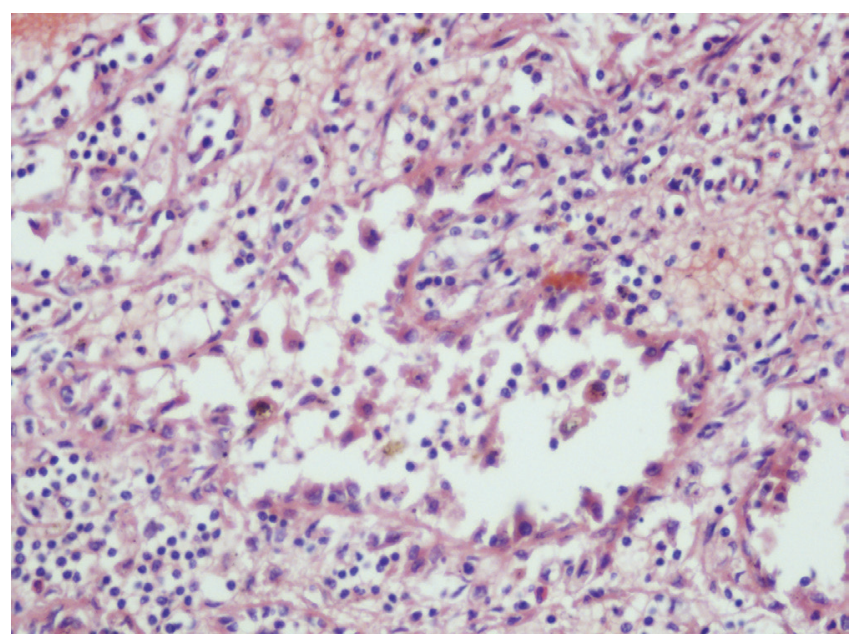

Figure 3. A higher-power view of the lesion demonstrates the characteristic histologic appearance of LCA. The vascular spaces are lined with plump endothelial cells. Some of these cells are sloughed off into the lumen (HE, X200). projections (Figure 2). Vascular spaces were lined by endothelial cells with oval-to-round large vesicular nuclei and small nucleoli, some of which had sloughed off into the lumen and these cells had vacuolated cytoplasm with focal erythrophagocytosis (Figure 3). Pleomorphism and mitotic activity were not seen.

Histochemically the lining cells were positively stained with periodic acid Schiff. The lining cells were immunoreactive for factor VIII, CD34, CD21, CD68 and in focal areas for S100 (Figure 4). The same cells were negative for CD31 (Figure 5). The staining pattern for type IV collagen in the lesion stroma did not differ from that of the surrounding splenic tissue. These findings were consistent with LCA.

\section{Discussion}

LCA was first described by Falk et al. in $1991[1,5,6]$. It is a rare, benign vascular tumor that probably originates from littoral cells of the red pulp, both endothelial and histiocytic differentiation [1]. LCA may occur at any age without any sex-based predilection $[7,8]$. Occasional cases in children have also been reported $[9,10]$.

Clinically, patients present with splenomegaly, abdominal pain and hypersplenism leading to thrombocytopenia and anaemia or, as in the case reported, as an incidental finding [11-13]. The malignant potential of LCA has not yet been firmly established in the literature [11]. Because an association with other malignancies, e.g. colonic and hepatocellular cancer, has been reported, close clinical follow-up of patients with LCA of the spleen is recommended $[11,13]$. In our case, following up for 1 year after surgery revealed no specific pathologic finding.

Most of the cases reveal multiple lesions. Solitary forms are rare $[9,12]$.

Microscopically, the lesions are composed of variably anastomosing vascular channels which are lined with flat or tall endothelial cells, and had irregular lumina, often featuring papillary projections and cyst-like spaces $[1,10]$. They usually slough off into the vascular lumina and exhibit hemophagocytosis $[1,13]$. Typically, few mitotic figures and no cytologic nuclear atypia are seen [13]. In our case, cyst-like areas, lined by tall endothelial cells, were located in the red pulp, but papillary projections were rare. Histochemically, we observed PAS positive endothelial cells, as mentioned in the literature [14].

The typical immunohistochemical pattern of LCA is as follows: CD31, CD68, CD163, CD21, FVIII antigen positive; CD34, CD8 negative $(6,11,13)$. Focal S100 positivity has been reported [1]. Our case had these immunohistochemical findings including the focal S100 positivity. 


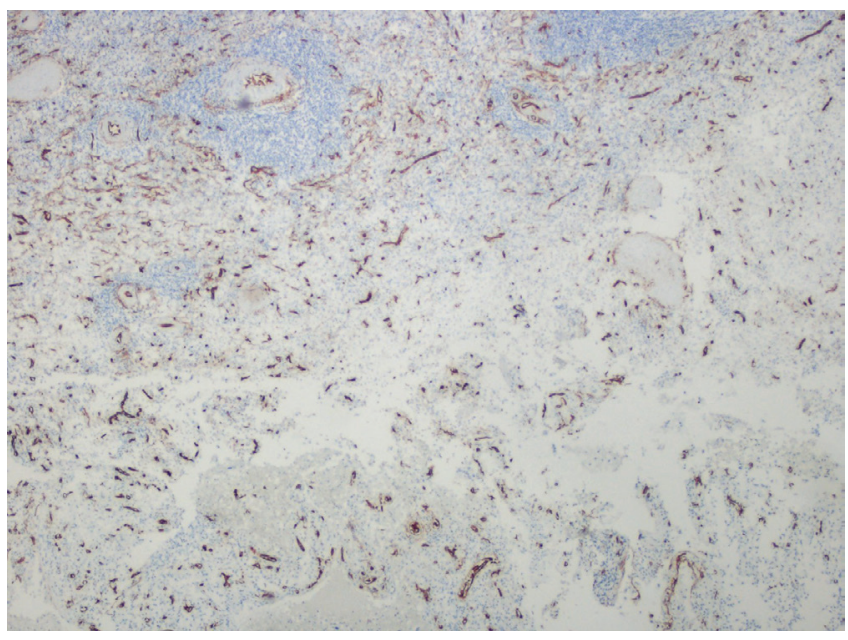

Figure 4. A lesion composed of vascular channels was negative for CD34 (IHK, X100).

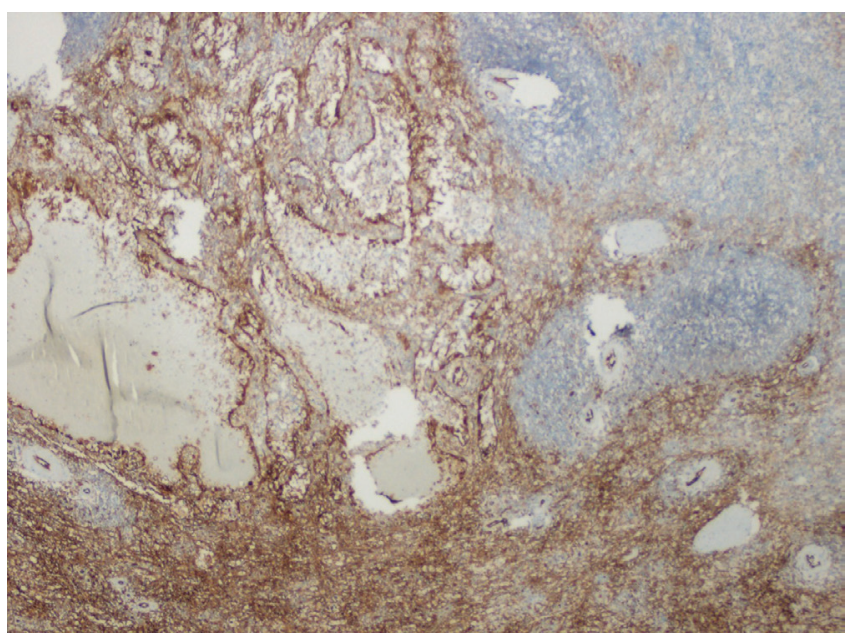

Figure 5. A lesion composed of vascular areas showed CD31 positivity. Normal splenic parenchyma is on the right (IHK, X100).

The differential diagnosis of LCA includes other vascular tumors of the spleen, namely splenic hemangioma, cystic lymphangioma, angiosarcoma and vascular hamartoma as well as peliosis [5]. Morphologic and immunophenotypic features allow one to distinguish LCA from other vascular tumors $[3,5]$.
In summary, this case shows histopathologic and immunohistochemical features of an LCA. Even though LCAs of the spleen are rare, they should be taken into consideration in the differential diagnosis of splenic vascular tumors.

\section{References}

1. Falk S, Stutte HJ, Frizzera G. Littoral cell angioma. A novel splenic vascular lesion demonstrating histiocytic differentiation. Am J Surg Pathol 1991;15:1023-33.

2. Arber DA, Strickler JG, Chen, YY, Weiss LM. Splenic vascular tumors: A histologic, immunophenotypic and virologic study. Am J Surg Pathol 1997; 21:827-35.

3. Musgrave NJ, Williamson RM, O'Rourke NA, Searle JW. Test and teach. Incidentally discovered splenic vascular lesion. Littoral cell angioma of the spleen. Pathology 2002;34:579-81.

4. Rosso R, Gianelli U, Chan J K C. Further evidence supporting the sinus lining cell nature of splenic littoral cell angiosarcoma. Am Surg Pathol 1996;20:1531. doi:10.1097/00000478-199612000-00014

5. Antón-Pacheco J, Fernandez Ayuso RM, Cano I, Martinez MA, Cuadros J, Berchi FJ. Splenic littoral cell angioma in an infant: Case report. J Pediatr Surg 2000;35:508-9.

6. Pilz JB, Sperschneider T, Lutz T, Loosli B, Maurer CA. Clinical image: Littoral cell angioma in main and accessory intrapancreatic spleen presenting as splenic rupture. Am J Surg 2011; 201: e15-e17.

7. Gupta P, Peungjesada S, Foshee S, Amirkhan RH. Littoral cell angioma of spleen: an uncommon presentation of a rare neoplasm. $\mathrm{J}$ Clin Imaging Sci 2012;2:69. doi: 10.4103/2156-7514.104302

8. Zong-Qiang H, Yong-Jun A, Qiang-Ming S, Wen L, Li L. The splenic littoral cell angioma in China: a case report and review. World J Surg Oncol 2011, 9:168-71. doi: 10.1186/1477-7819-9-168

9. Matuszczak E, Reszec J, Dębek W, Hermanowicz A, Chyczewski L. Is littoral cell angioma of the spleen as rare as previously believed in the pediatric population? Folia Histochemica et. 2012;50: 480-5. doi: 10.5603/FHC.2012.0067

10. Kranzfelder M, Bauer M, Richter T. Littoral cell angioma and angiosarcoma of the spleen: Report of two cases in siblings and review of the literature. J Gastrointest Surg 2012; 16: 863-7. doi: 10.1007/ s11605-011-1773-6

11. Priego P, Rodríguez G, Velasco P, Griffith S, Fresneda V. Littoral cell angioma of the spleen. Clin Transl Oncol 2008; 10: 61-3. doi: 10.1007/s12094-008-0155-3

12. Liang W, Lu J, Qin M, Sang X. Littoral cell angioma mimicking hepatic tumor. Acta Radiol Short Rep 2012;1: 23-26. doi: 10.1258/ arsr.2012.120031

13. Chourmouzi D, Psoma E, Drevelegas A. Littoral cell angioma, a rare cause of long standing anaemia: a case report. Cases J 2009; 2: 9115-18. doi: 10.1186/1757-1626-2-9115

14. Braester A, Manaster J, Cohen I. Coexistence of littoral cell angioma in spleen with Evans syndrome. J Hellenic Soc Haematomy (HAEMA) $2005 ; 2: 203-5$. 